\title{
Collaborative Research on Dusky Grouper (Epinephelus marginatus): Catches from the Small-Scale Fishery of Copacabana Beach, Rio De Janeiro, Brazil
}

\author{
Alpina Begossi ${ }^{*}$, Svetlana Salivonchyk ${ }^{2}$ and Renato Silvano AM $^{3}$ \\ ${ }^{1}$ CAPESCA/NEPA/UNICAMP \& Fisheries and Food Institute, Ecomar, Unisanta, Rua Cesário Mota, Santos, Brazil \\ ${ }^{2}$ Institute for Nature Management, National Academy of Sciences of Belarus, Minsk, Belarus \\ ${ }^{3}$ Department of Ecology, Universidade Federal do Rio Grande do Sul (UFRGS), Fisheries and Food Institute, Porto Alegre, RS, Brazil
}

\begin{abstract}
The dusky grouper (Epinephelus marginatus) is a reef fish with high market, cultural and ecological values. Therefore, it is an important species to the food security of small-scale fishers in Brazil and in other coastal regions. Nevertheless, groupers can be susceptible to overfishing because they are large, sedentary and with delayed maturity. The lack of data on fishery catches and on the biology of dusky grouper can be an obstacle for the success of management measures. The main goal of this study was to collect information on dusky grouper catches, morphometry (length and weight) and spawning period (observations of its gonads), through a collaboration with local fishers in the Copacabana Beach ("Posto 6"), southeastern Brazilian coast. Two fishers were trained to measure the total length $(\mathrm{TL}$, in $\mathrm{cm}$ ), weight $(\mathrm{kg})$, and to observe the gonads (whether mature or not, and with or without visible eggs) of all individuals of dusky grouper caught at Copacabana, from September 2013 to June 2015. During the 21 months of data collection, 800 individuals of dusky grouper were examined by the trained fishers, yielding 793 individuals with both length and weight data. The mean length of dusky grouper caught by fishers $(\mathrm{N}=796)$ was $52.4 \mathrm{~cm}$ (standard deviation of $12.4 \mathrm{~cm}$, range from $17-130 \mathrm{~cm}$ ). Most of the individuals caught ranged between 45 and $65 \mathrm{~cm}$, being thus above both the minimum allowed size in Brazil $(47 \mathrm{~cm})$ and above the size at first maturity for this fish according to the literature (range of $35-60 \mathrm{~cm}$ for females). Although many individuals were adults, only a few individuals (18 of 800 ) of dusky grouper had mature gonads. This indicates that large spawning fish may be located at deeper sites or at distant spots, out of the reach of these small-scale fishers. Most dusky groupers were caught by spear fishing, in a single island. The collaboration with local fishers greatly improved the amount of data collected; so, we suggest that this approach should be adopted in future studies. These results show a valuable opportunity to properly manage the dusky grouper population at the southeastern Brazilian coast.
\end{abstract}

Keywords: Brazilian small-scale fisheries; Reef fish; Fish reproduction; Fisheries management; Epinephelus marginatus; Dusky grouper

\section{Introduction}

Epinephelid groupers include about 160 species, which are ecologically and economically important, being distributed along subtropical and tropical seas [1]. The dusky grouper is one of the most common fishes in the Adriatic [2] and in the Mediterranean [3], being important economically and recreationally. A protogynous hermaphrodite fish, the dusky grouper reaches female sexual maturity at $3 \mathrm{~kg}$ of weight, showing a mean length at first maturity $\left(\mathrm{L}_{50}\right)$ of 43.8 $\mathrm{cm}\left(\mathrm{L}_{\mathrm{s}}\right)$; its sex reversal to the male occurs at $10 \mathrm{~kg}$ with a $\mathrm{L}_{50}$ of $81.3 \mathrm{~cm}$ $\left(\mathrm{L}_{\mathrm{s}}\right)[2,3]$. The largest specimens of this fish were caught in Tunisia $(35$ $\mathrm{kg})$ and in Brazil $(60 \mathrm{~kg})$ [2]. The dusky grouper has been described in the literature as a solitary and territorial fish with a maximum length of $150 \mathrm{~cm}$, maximum observed age of 50 years and with its distribution in the Atlantic Ocean [4-7]. This fish is very important and high-valued in the Mediterranean Sea, where there are many aquaculture initiatives to raise dusky grouper $[8,9]$. Nevertheless, groupers can be susceptible to overfishing because they are large, sedentary and with delayed maturity [10]. Declines in the fish stocks of dusky grouper and other grouper species have been observed in many regions, including the Brazilian coast, Mediterranean and Gulf of California, usually through studies using historical information or fishers' knowledge due to the lack of data on catches [11-14].

Reef fishes, such as the dusky grouper, are of great importance for artisanal fisheries off the coast of Brazil, according to previous studies on small-scale fishers, which include 1,761 data on fish landings [15]. In Brazilian small-scale fisheries, the dusky grouper is a particularly important food source, as this fish is considered as tasty, having a high market value, besides being recommended to be eaten by unhealthy persons during convalescence [16,17]. This importance and multiple uses indicate that dusky grouper has a high market, cultural and ecological value. Therefore, this fish can be considered as an important species concerning the food security of small-scale fisheries in Brazil $[15,17,18]$. Data on dusky grouper reproduction are very scarce in the Brazilian coast [19]. Individuals of this species, regularly caught by fishers, frequently include immature females with an absence of sexually mature individuals $[18,20]$. Therefore, it is very important to sample larger numbers of individuals of the dusky grouper to acquire more data on its reproduction in Brazil. An earlier study at the smallscale fishery of Copacabana, in the southeastern Brazilian coast, shows how difficult it is to obtain data on the spawning period of this fish

*Corresponding author: Alpina Begossi, Fisheries and Food Institute, Ecomar Unisanta, Rua Cesário Mota, 08, CAPESCA/NEPA/UNICAMP, Campinas, SP (Rua Albert Einstein, s/n), 13083-852, Brazil, Tel: 55-19-78084276; E-mail: alpinab@ uol.com.br

Received April 04, 2016; Accepted May 25, 2016; Published May 31, 2016

Citation: Begossi A, Salivonchyk S, Renato Silvano AM (2016) Collaborative Research on Dusky Grouper (Epinephelus Marginatus): Catches from the SmallScale Fishery of Copacabana Beach, Rio De Janeiro, Brazil. J Coast Zone Manag 19: 428. doi:10.4172/2473-3350.1000428

Copyright: $\odot 2016$ Begossi A, et al. This is an open-access article distributed under the terms of the Creative Commons Attribution License, which permits unrestricted use, distribution, and reproduction in any medium, provided the original author and source are credited. 
Citation: Begossi A, Salivonchyk S, Renato Silvano AM (2016) Collaborative Research on Dusky Grouper (Epinephelus Marginatus): Catches from the Small-Scale Fishery of Copacabana Beach, Rio De Janeiro, Brazil. J Coast Zone Manag 19: 428. doi:10.4172/2473-3350.1000428

Page 2 of 6

[18]. Previous studies have also emphasized the importance of the local knowledge of fishers, in order to improve biological knowledge, on the reproduction of the dusky grouper and of the other target fishes [18,21-23].

The objective of this study was to collect information on dusky grouper catches, morphometry (length and weight) and spawning period (observations of its gonads) in the small-scale fishery of Copacabana Beach ("Posto 6"), southeastern Brazilian coast. We compared the sizes of individuals of dusky grouper caught by diving (spear fishing) with those caught by using other, less selective fishing gear (line and gillnet). We also compared the sizes of groupers caught at distinct fishing spots. These results should contribute to filling existing knowledge gaps about the biology of this important fish, thus helping to improve its conservation and management.

\section{Methods}

\section{Study site}

Copacabana Beach includes a small-scale fishing community ("Colonia do Posto 6 ") created in 1923, where groupers have been a target fish and a "noble fish", which means a high-priced commercial fish [24]. Fishing at Copacabana Beach (Figure 1) is performed with small-scale motor canoes or boats using nets, hooks and lines and by spear fishing [25]. Recently, spear fishing through diving has become important, especially among young fishers.

\section{Sampling procedures}

One of the authors $(\mathrm{AB})$ undertook fieldwork from September 25, 2013 to June 11, 2015 at the landing point of the Colonia de Pescadores Z-13 ("Posto 6"), at Copacabana. Data collection methods included collaborating with two fishers after training them following a protocol conducted by $\mathrm{AB}$. The protocol included measuring the TL (total length in $\mathrm{cm}$ ) and weight $(\mathrm{kg})$ of the fish, in addition to open the fish to be able to observe its gonads (whether mature or not, and with or without visible eggs). This procedure of macroscopically observing the mature gonads of the fish was previously used in other studies with snook (Centropomus undecimalis) [22], bluefish (Pomatomus saltatrix) [23] and dusky grouper $[15,17,18,26]$. "Macroscopical observation" means that the gonads are observed through a naked eye.

Two fishermen known from previous studies at Copacabana Beach $[18,25]$ were selected to participate in this study. In addition to being fishers, these collaborators are also fish cleaners who clean and cut fish fillets. In this fishery, fish catches are placed at stands and sold by

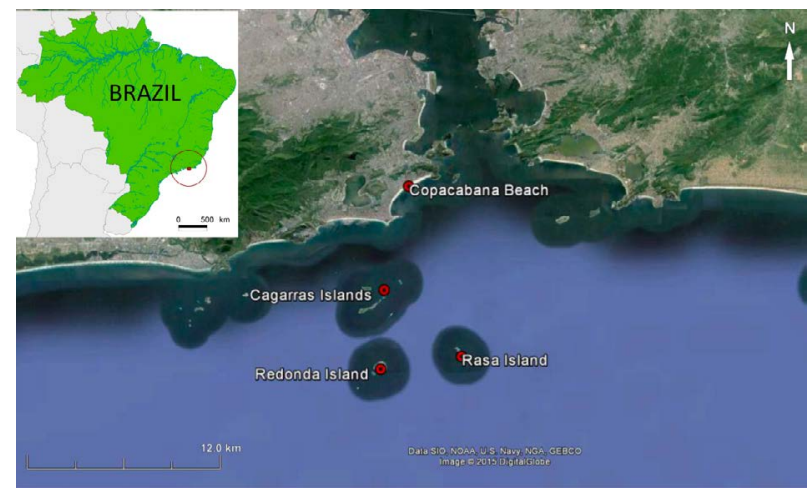

Figure 1: Map of the study area (Copacabana beach, Rio de Janeiro, Brazil) with importante fishing spots used in the small-scale fishery to obtain catches, including the dusky grouper E. marginatus. fishers. The sold groupers are sent to the fish cleaners, who clean the fish for the consumers. Once or twice a month, AB collected these data from the collaborators, along with other relevant information. These two fishers were paid by $\mathrm{AB}$ through a grant.

The size frequencies of the groupers caught were compared between two kinds of fishing gear: diving (spear) and others (line and gillnets), through a Kolmogorov-Smirnov test of two distributions. The median sizes of groupers caught were compared among fishing spots through a non-parametric Kruskal-Wallis test (data did not show a normal distribution, even after transformations).

\section{Results}

During the 21 months of sampling, 800 individuals of dusky grouper (Epinephelus marginatus) were caught, measured and examined by the trained fishers. The lengths of four and the weights of three groupers could not be measured, resulting in a sample of 793 individuals with both length and weight measured. The mean length of the groupers was $52.38 \mathrm{~cm}(\mathrm{~N}=796)$ with a standard deviation of $12.35 \mathrm{~cm}$, and the length range was $17-130 \mathrm{~cm}$. Most of the individuals caught had lengths between 45 and $65 \mathrm{~cm}$ (Figure 2).

The mean weight of the groupers collected was $3.05 \mathrm{~kg}(\mathrm{~N}=797)$,

\begin{tabular}{|c|c|c|c|c|c|c|c|c|c|c|}
\hline \multirow[b]{2}{*}{ Month } & \multicolumn{2}{|c|}{ Length, cm } & \multicolumn{2}{|c|}{$\begin{array}{l}\text { St dev of } \\
\text { Length }\end{array}$} & \multicolumn{2}{|c|}{$\begin{array}{l}\text { Weight, } \\
\text { kg }\end{array}$} & \multicolumn{2}{|c|}{$\begin{array}{l}\text { St dev of } \\
\text { Weight }\end{array}$} & \multicolumn{2}{|c|}{$\begin{array}{c}\text { Number of } \\
\text { fish }\end{array}$} \\
\hline & 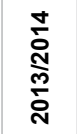 & 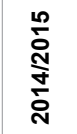 & 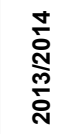 & 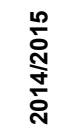 & 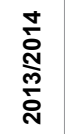 & 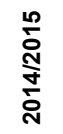 & 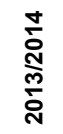 & 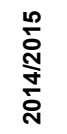 & 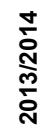 & 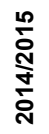 \\
\hline Sep & 44.86 & 51.20 & 6.07 & 11.61 & 2.00 & 2.76 & 0.50 & 3.25 & 7 & 66 \\
\hline Oct & 50.71 & 51.41 & 11.50 & 9.72 & 2.93 & 2.60 & 2.47 & 1.87 & 24 & 76 \\
\hline Nov & 47.57 & 53.74 & 9.51 & 10.75 & 2.21 & 3.24 & 1.56 & 2.58 & 23 & 87 \\
\hline Dec & 72.00 & 56.61 & & 11.08 & 5.48 & 3.37 & & 2.35 & 1 & 24 \\
\hline Jan & 65.74 & 54.35 & 18.46 & 11.85 & 7.06 & 3.27 & 8.01 & 2.93 & 10 & 68 \\
\hline Feb & 55.10 & 53.67 & 18.25 & 8.02 & 4.55 & 2.65 & 4.59 & 1.20 & 20 & 33 \\
\hline Mar & 46.21 & 53.79 & 7.44 & 10.78 & 2.19 & 3.10 & 1.10 & 2.32 & 28 & 29 \\
\hline Apr & 45.16 & 56.39 & 16.86 & 16.49 & 2.76 & 4.71 & 2.27 & 6.22 & 31 & 28 \\
\hline May & 50.69 & 62.60 & 12,64 & 14.78 & 2.86 & 5.03 & 3.64 & 3.45 & 75 & 15 \\
\hline Jun & 45.67 & 57.00 & 5.73 & 11.38 & 1.65 & 3.81 & 0.59 & 2.65 & 24 & 31 \\
\hline
\end{tabular}

Table 1: Mean and Standard Deviation of Length and Weight of E. marginatus $(\mathrm{N}=700$ ) catches by month at Copacabana beach (Rio de Janeiro, Brazil), from September 2013 to June 2015.

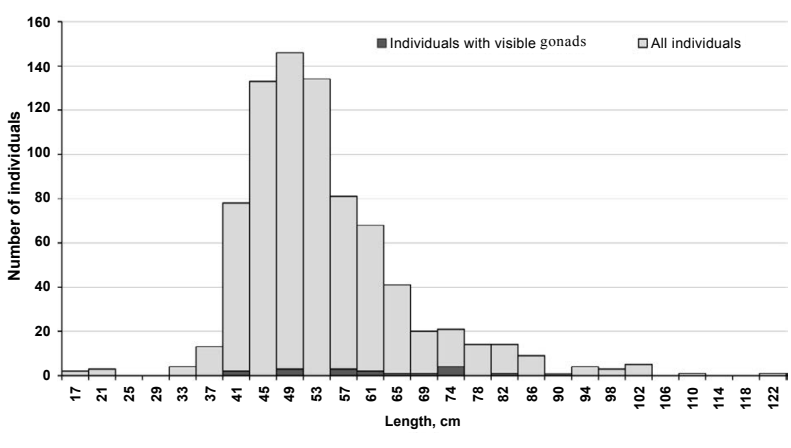

Figure 2: Frequencies of length and presence of visible gonads of the groupers ( $E$. marginatus, $\mathrm{n}=796$ ) collected from September 2013 through June 2015, Copacabana beach, Brazil. Mean length is $52.38 \mathrm{~cm}(\mathrm{~N}=796)$; Standard Deviation $12.35 \mathrm{~cm}$; the length range is $17-130 \mathrm{~cm} . \mathrm{Y}=$ number of individuals. 
Citation: Begossi A, Salivonchyk S, Renato Silvano AM (2016) Collaborative Research on Dusky Grouper (Epinephelus Marginatus): Catches from the Small-Scale Fishery of Copacabana Beach, Rio De Janeiro, Brazil. J Coast Zone Manag 19: 428. doi:10.4172/2473-3350.1000428

Page 3 of 6

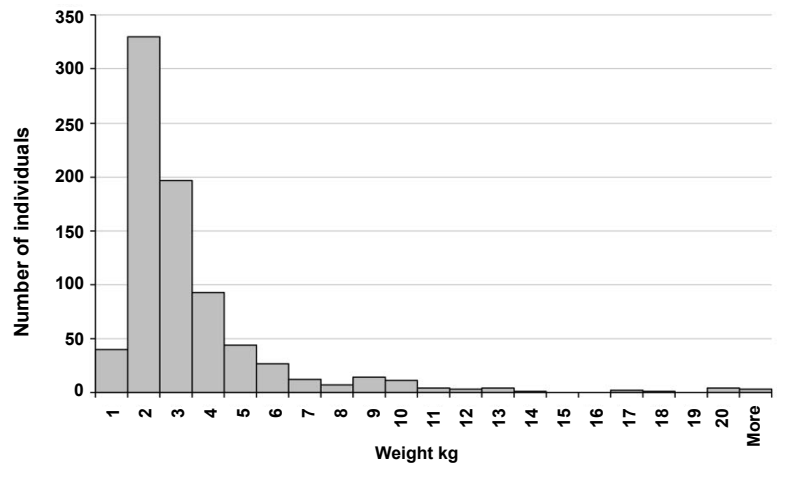

Figure 3: Frequency of weight $(\mathrm{kg})$ of the groupers (E. marginatus, $\mathrm{N}=$ 797) collected from September 2013 through June 2015 at Copacabana beach, Rio de Janeiro, Brazil. Mean weight is $3.05 \mathrm{~kg}(\mathrm{~N}=797)$; Standard Deviation is 3.03 ; the range of weight is $0.72-33.2 \mathrm{~kg}$.

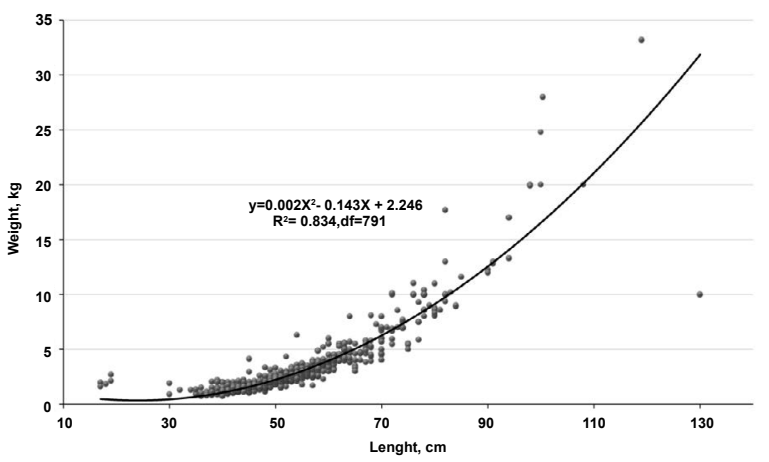

Figure 4: Weight - Length relationships for the catches of $E$. marginatus at Copacabana beach, 2013-2015. Regression equation: $y=0.002 x^{2}-$ $0.143 x+2.246 ; R^{2}=0.83 ; d f=791$.

with a standard deviation of 3.03; the weight range was $0.72-33.2 \mathrm{~kg}$, and most individuals had weights between 2 and $4 \mathrm{~kg}$ (Figure 3 ).

Table 1 shows the catches of dusky grouper at Copacabana during 2013-2015, which were obtained after 42 fieldwork visits by one of the authors $(\mathrm{AB})$ and 205 days of fish observations by the two collaborative fishers. Large individuals of dusky grouper were caught in the summer (January and February) and autumn (May). In May 2014 many individuals were caught (similar to the spring of 2015) (Table 1). The weight-length relationship of dusky grouper $(n=793)$ is shown in Figure 4.

Of the 800 dusky groupers examined, only 18 had mature gonads, 15 of which were collected, ranging from $15-48 \mathrm{ml}$ (Table 2). These mature fish were mostly caught at Cagarras Island in the summer, especially in November (Figure 5). The weights of the mature dusky groupers ranged from $1.95-8.6 \mathrm{~kg}$, and the lengths ranged from $40-81 \mathrm{~cm}$.

Most dusky groupers (57\%) were caught at the Cagarras Islands (Figure 5). The median size of groupers caught differed among fishing spots $(\mathrm{H}=19.2$, d.f. $=9, \mathrm{p}<0.05)$. Just a few large groupers were caught at two distant fishing areas, located about $460 \mathrm{~km}$ (Angra dos Reis) and $640 \mathrm{~km}$ (Cabo Frio) from the city of Rio de Janeiro (Figure 5). If we excluded these two distant spots from the analysis, the size of groupers caught did not differ among the other fishing spots $(\mathrm{H}=8.2$, d.f. $=7$, $\mathrm{p}$ $=0.32$ ). The median size of groupers caught at all these fishing spots was around $50 \mathrm{~cm}$ length (Figure 6).
Considering the 299 dusky groupers to which data were available regarding fishing methods, 91\% were caught through spear fishing during snorkeling (one of the fishers who collaborate in this study uses this method). Notwithstanding that much more groupers were caught by spear fishing $(\mathrm{n}=271)$, compared to other fishing techniques (line and gillnets, $\mathrm{N}=28$ ), the frequency of size classes of groupers caught did not differ between spear fishing and the other gears $(p>0.05$, Figure 7$)$.

\section{Discussion}

The support and collaboration of the two fishers from Copacabana beach increased our sampling effort and hence the efficiency of the research. When comparing these results with an earlier study on dusky grouper at Copacabana Beach performed in 2006-2007 during 19 months with 36 days of fieldwork [18], we observe that the collaborative process with the fishers allowed us to almost double our sampling effort (42 days of fieldwork, 205 examination days and 800 fish examined)

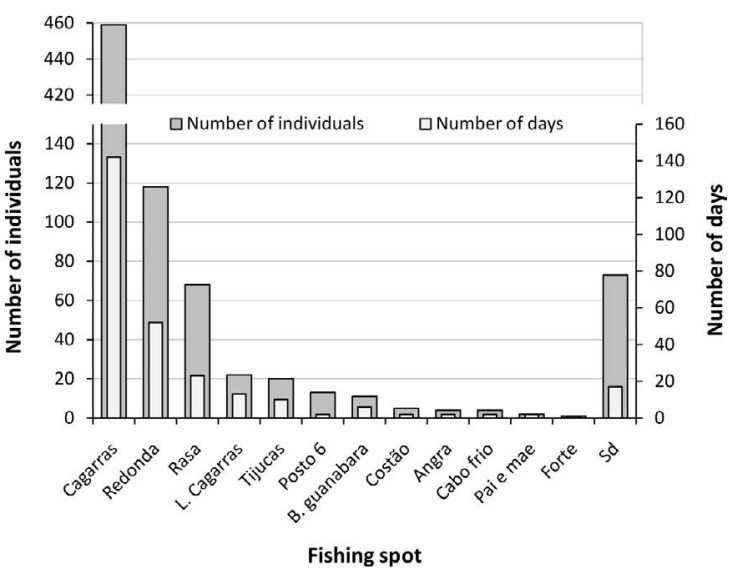

Figure 5: The main fishing spots used by fishers from Copacabana beach Rio de Janeiro, Brazil, from which the sampled individuals of dusky grouper (E. marginatus) were caught. Percent of individuals mean the percent of groupers caught in each fishing spot $(\mathrm{N}=793)$. The percent of days means the fishing effort $(\mathrm{N}=205)$. "Ao largo das Cagarras" is an area close to Cagarras, but offshore Cagarras Islands. $\mathrm{Sd}=$ no data on spots. B.gunabara $=$ Guanabara bay.

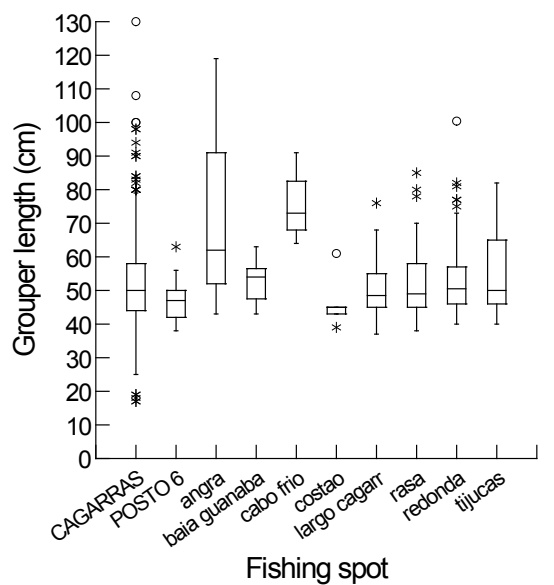

Figure 6: Comparison of median sizes (line in the middle of boxes) of groupers (E. marginatus) caught among fishing spots in the Copacabana beach, Rio de Janeiro, Brazil. Numbers of groupers caught in each fishing spot are in Figure 5. baia guanaba = Guanabara bay. 
Citation: Begossi A, Salivonchyk S, Renato Silvano AM (2016) Collaborative Research on Dusky Grouper (Epinephelus Marginatus): Catches from the Small-Scale Fishery of Copacabana Beach, Rio De Janeiro, Brazil. J Coast Zone Manag 19: 428. doi:10.4172/2473-3350.1000428

\begin{tabular}{|c|c|c|c|c|}
\hline Date & Length (cm) & Weight $\mathbf{( k g})$ & Gonad volume (ml) & Fishing spot \\
\hline $\mathbf{1 0 / 0 9 / 1 3}$ & 40 & 1.95 & 15 & Cagarras Islands \\
\hline $\mathbf{1 1 / 1 2 / 1 3}$ & 42 & 1.38 & 48 & Cagarras Islands \\
\hline $\mathbf{1 1 / 1 4 / 1 3}$ & 48 & 1.92 & 22 & Cagarras Islands \\
\hline $\mathbf{1 1 / 0 3 / 1 3}$ & 56 & 3.46 & 38 & Cagarras Islands \\
\hline $\mathbf{1 1 / 0 3 / 1 3}$ & 59 & 3.42 & 40 & Cagarras Islands \\
\hline $\mathbf{1 1 / 1 4 / 1 3}$ & 63 & 5.15 & 45 & Cagarras Islands \\
\hline $\mathbf{1 1 / 1 4 / 1 3}$ & 49 & 2.30 & 25 & Cagarras Islands \\
\hline $\mathbf{1 2 / 0 9 / 1 3}$ & 72 & 5.48 & 30 & Cagarras Islands \\
\hline $\mathbf{1 1 / 2 5 / 1 4}$ & 70 & 6.00 & 20 & Cagarras Islands \\
\hline $\mathbf{1 1 / 2 5 / 1 4}$ & 81 & 8.60 & 20 & Redonda Island \\
\hline $\mathbf{0 1 / 0 7 / 1 5}$ & 64 & 5.70 & 30 & Cagarras Islands \\
\hline $\mathbf{0 1 / 0 7 / 1 5}$ & 62 & 4.30 & 29 & Cagarras Islands \\
\hline $\mathbf{0 2 / 0 4 / 1 5}$ & 48 & 1.79 & 30 & Rasa Island \\
\hline $\mathbf{0 2 / 0 4 / 1 5}$ & 59 & 2.97 & 25 & Redonda Island \\
\hline $\mathbf{0 4 / 1 5 / 1 5}$ & 72 & 6.67 & 25 & Cabo Frio \\
\hline
\end{tabular}

Table 2: Macroscopically visible gonads of E. marginatus, with visible eggs (oocites) from dusky groupers examined from catches from Copacabana beach (Rio de Janeiro, Brazil), from September 2013 through June 2015. Three dusky groupers observed in April had mature gonads, but they were not collected.

\begin{tabular}{|c|c|c|}
\hline Month & $\mathbf{2 0 1 4}$ & $\mathbf{2 0 0 6 - 2 0 0 7}$ \\
\hline Feb & 20 & 5 \\
\hline Mar & 28 & 5 \\
\hline Apr & 31 & 9 \\
\hline May & 75 & 2 \\
\hline Jun & 24 & 0 \\
\hline Jul & 66 & 2 \\
\hline Aug & 34 & 2 \\
\hline Sep & 66 & 2 \\
\hline Oct & 76 & NS \\
\hline Nov & 87 & 9 \\
\hline Total & 507 & 36 \\
\hline
\end{tabular}

Table 3: Comparisons of results (number of fish sampled) from research on dusky grouper (Epinephelus marginatus) sampled in 2006, 2007 (just the researcher) and in 2014 (with fishers' collaboration) in Copacabana beach, Rio de Janeiro, Brazil.

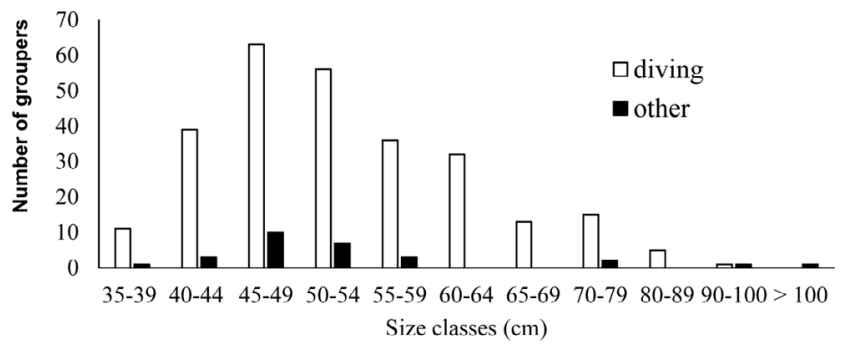

Figure 7: Frequency of individuals of groupers (E. marginatus) of distinct size classes caught by spear fishing $(n=271)$ or by other fishing gears (lines and gillnets, $n=28$ ) in the Copacabana beach, Rio de Janeiro, Brazil.

(Table 3). We examined 507 dusky groupers in 2014 in a monthly basis, compared to 24 in 2006 and 12 in 2007 [18]. Compared to other studies [20], we obtained a relatively large sample of 800 groupers in this study, 18 of which had mature gonads in which oocytes were macroscopically visible. Earlier preliminary results of research with dusky groupers have indicated that the research protocol including collaborative processes with fishers was valuable enough in order to proceed with this kind of methodology [26].

Since the pioneering work of Johannes [27], Ruddle [28] and Berkes [29], many other researchers have successfully collaborated with fishers. Some of these collaborative studies have been conducted in the Brazilian coast $[18,21,22,30]$, in the small-scale Amazonian fisheries, in Australian rivers and with Mayan lobster fishers [31-33]. Furthermore, an important set of small-scale fishery researchers have performed collaborative research with small-scale fishers in Latin America, as exemplified in a recent FAO technical paper [34]. Research can be improved if biologists and ecologists would have, first, a better understanding of the empirically based fishers' knowledge; second, a perception on their interest in participating in research connected with their fishery; and finally, a comprehension on the importance of an interactive dialogue with fishers for successful fishery management.

Fishermen caught most of the groupers shown here by spear fishing during snorkeling. Glamuzina and Skaramuca [2] observed that this species is especially exposed to spear fishing due to its way of life and attitude towards divers. In the south of Brazil, line fishing is the most important method for catching the dusky grouper [35]. Our previous studies of other small-scale reef fisheries show that hook and line is an important method to catch dusky grouper [25,36,37]. However, at the Copacabana Beach, young fishers have been moving toward snorkeling and spear fishing, which is currently an important fishing method. Fishing through diving may represents either an opportunity or a challenge to the management of dusky grouper fisheries. Diving is usually a highly selective fishing method, which allows fishers to direct effort to catch the largest individuals in a population. Such size selectiveness may remove large fish with important ecological functions (for example, predators), besides having great reproductive and survival potential $[38,39]$. We observed that overall size frequencies of groupers caught did not differ between diving and other, less selective fishing gears (the number of fishing trips using other fishing gears was lower compared to diving). Moreover, although not statistically significant, we observed a possible trend of large groupers (from 60 to $89 \mathrm{~cm}$ ) being more often caught by diving (Figure 7). Therefore, the potential impacts of diving should be properly assessed in comparison with the impacts of other fishing techniques. The popularity of diving among fishers in the studied region may require future management measures aimed to avoid capture of larger fish, such as zoning with no-take areas [7]. On the other hand, diving fishers have often a good knowledge about fish, such as about its behavior and habitat. Such knowledge could help to develop co-management measures aimed to groupers [40,41].

Mature gonads were found in the catches at Copacabana in groupers with lengths from $40-81 \mathrm{~cm}$ (Table 2). According to Marino et al. [3], the first sexual maturity of dusky groupers occurs at lengths of $36.7 \mathrm{~cm}$ in females and $68.5 \mathrm{~cm}$ in males, corresponding to ages of 5 and 12 years, respectively. Froese and Pauly [7] show the length at first maturity $\left(\mathrm{L}_{50}\right)$ of females to be $47 \mathrm{~cm}$. In Brazil, the $\mathrm{L}_{50}$ of the females of dusky grouper is considered to be $47 \mathrm{~cm}$ with a range of $35-60 \mathrm{~cm}$ [19]. The minimum length we obtained in our study was a $40 \mathrm{~cm}$ female with mature gonads. This is within the range observed by Andrade et al. [19] and Marino et al. [3]. The minimum legal size in Brazil is $47 \mathrm{~cm}$ for $E$. marginatus (garoupa) [42]. However, considering that this information is very important in the management of a fishery, it is reasonable to suggest that the minimum legal size for catching grouper should be reduced to $40 \mathrm{~cm}$. Fishers should be consulted about this management measure, which might be well accepted, as most of the dusky grouper caught were larger than $40 \mathrm{~cm}$ (Figure 2).

Mature groupers were observed in Copacabana Beach, especially in the summer and specifically in November. These results agree with earlier studies on reproduction of this fish from other areas in Brazil $[19,20]$. 
Citation: Begossi A, Salivonchyk S, Renato Silvano AM (2016) Collaborative Research on Dusky Grouper (Epinephelus Marginatus): Catches from the Small-Scale Fishery of Copacabana Beach, Rio De Janeiro, Brazil. J Coast Zone Manag 19: 428. doi:10.4172/2473-3350.1000428

As in our earlier studies $[15,17,18]$, the number of immature individuals was relatively high, because only 18 individuals out of 800 were found with mature gonads. Other studies also found a high proportion of young individuals [20,35]. We agree with Condini et al. [20] that spawning groupers should be located at deeper ranges; however, we also suggest that the hypothesis that spawning groupers could be located in rocky areas far from the shoreline can be very plausible [43]. Areas far from the shore or at greater depth ranges are sites that smallscale fishers usually cannot reach with their technologies (see fishing spots for groupers used by small-scale fisheries of Copacabana in [18]. Based on information from SCUBA divers, Bodilis et al. [44] observed that small dusky groupers $(\leq 25 \mathrm{~cm} \mathrm{TL})$ are frequently observed in shallow waters; groupers from $20-25 \mathrm{~cm}$ are found at depths of $\geq 30$ $\mathrm{m}$, and the largest individuals (over $40 \mathrm{~cm}$ ) at depths from 15-60 m (but groups of all sizes are present in shallow waters). Thus, mature and larger females may be more out of reach for most small-scale fishers in the studied region (Copacabana, Rio de Janeiro).

The fishing spots used at Copacabana include coastline islands, such as the Cagarras Islands and others, such as Rasa and Redonda. We mapped the fishing spots used for groupers, including those in the Cagarras Islands in previous studies $[25,45]$. This study confirms the importance of the Cagarras Islands as sites for dusky grouper fishing. Moreover, most mature groupers came from this area. Even though we consider the importance of that area, it is important to note that most groupers caught by fishers are over $40 \mathrm{~cm}$ in length. Larger groupers were caught at more distant fishing spots. Cagarras Island showed the largest variation in the sizes of groupers caught, including the largest individual caught by fishers (Figure 6).

The fact that a few individuals caught were mature helps explaining why such an important target fish does not seem overexploited yet. Scarcities of spawning fishes in landings could be an indicator of both recruitment and growth overfishing, as juveniles are caught before reaching reproductive size [46]. Indeed, a previous study suggests that the lack of knowledge of fishers about the reproduction of large pelagic fish may be an indicator of overfishing [21]. In this study we observed that most of the non-spawning fish were large individuals, beyond the size at first maturity. This may indicate that fishers are not targeting large reproductive fish, for example in spawning aggregations [41]. A previous genetic study of E. marginatus using microsatellite markers in the Paraty bay (southern coast of Rio de Janeiro State) suggested panmixia and a single stock with an $\mathrm{N}_{\mathrm{E}}$ (effective population size) estimated at 663 individuals. This number could represent the threshold of the population capacity for avoiding genetic loss, due to genetic drift [47].

\section{Conclusions}

This study provided useful information to fisheries management of the dusky grouper, an important reef fish with high commercial value and targeted by many small-scale fisheries, including those in the Brazilian coast. The collaboration with local fishers greatly improved the amount of data collected and the overall consistency of the research. We thus recommend that this approach should be more broadly adopted in future studies. Fishing of dusky grouper is concentrated especially in a single archipelago (Cagarras), mostly done through spear fishing, which represents opportunities and challenges to management. Our results indicate that catches consist mostly of large adults, indicating a possibly non-overexploited stock of dusky grouper. Nevertheless, very few individuals were observed with mature gonads. We suggest that reproductive fish may be in deeper sites, out of reach of these smallscale fishers, or far from shore. Although important for management, these ecological patterns remain as hypotheses to be checked in future studies.

\section{Acknowledgements}

We are grateful to FAPESP - Fundação de Amparo à Pesquisa do Estado de São Paulo for visiting researcher scholarship to SS (Processo FAPESP $N^{\circ} 14 / 24994$ 8 and 14/16939-7), and to CNPq - Conselho Nacional de Desenvolvimento Científico e Tecnológico for productivity scholarships to $\mathrm{AB}$ (Processo $\mathrm{CNPq} \mathrm{N}^{\circ}$ 302762/2013-0) and to RAMS (Processo CNPq N³09014/2013-1). In particular the grant from CNPq to AB supported the fieldwork.

\section{References}

1. DeMartini EE, Everson AR, Nichols RS (2011) Estimates of body sizes at maturation and at sex change, and the spawning sesonality and sex ratio of the endemic Hawaiian grouper (Hyporthodus quernus, F. Epinephelidae). Fish. Bull 109:123-134.

2. Glamuzina B, Skaramuca B (1999) A review: Adriatic groupers-Status of natural populations and breeding perspectives. Acta Adriatica 40: 79-90.

3. Marino G, Azzurro E, Massari A, Finoia MG, Mandich A (2001) Reproduction in the dusky grouper from the southern Mediterranean. Journal of Fish Biology 58: 909-927.

4. Figueiredo JL, Menezes NA (1980) Manual de peixes marinhos do sudeste do Brasil. III. Teleostei (2). Museu de Zoologia, Universidade de São Paulo. Brasil: 90.

5. Heemstra PC, Randall JE (1993) Groupers of the World (Family Serranidae, Subfamily Epinephelinae) An annotated and illustrated catalogue of the grouper, rockcod, hind, coral grouper and lyretail species known to date. FAO Species Catalogue, FAO Fish Synop 16: 125.

6. Gothel H (1994) Fauna marina del mediterráneo: animales inferiores y peces. Omega, Barcelona.

7. Froese R, Pauly D (eds) (2015) FishBase. World Wide Web electronic publication.

8. Glamuzina B, Kožul V, Skaramuca B (2000a) Female reproductive cycle of the dusky grouper, Epinephelus marginatus (Lowe, 1834) in captivity. Acta Adriatica 41: 79-88.

9. Glamuzina B, Skaramuca B, Kožul V, Tutman P (2000b) Status of grouper (genus Epinephelus) investigations in Croatia. Cahiers Options Méditerranéennes 47 235-239.

10. Sadovy de Mitcheson Y, Craig MT, Bertoncini AA, Carpenter KE, Cheung WW, et al. (2013) Fishing groupers towards extinction: a global assessment of threats and extinction risks in a billion dollar fishery. Fish and Fisheries 14: $119-136$.

11. Sáenz-Arroyo A, Roberts CM, Torre J, CariñOlvera M (2005) Using fishers' anecdotes, naturalists' observations and grey literature to reassess marine species at risk: the case of the Gulf grouper in the Gulf of California, Mexico. Fish and Fisheries 6: 121-133.

12. Guidetti $P$, Micheli $F$ (2011) Ancient art serving marine conservation. Frontiers in Ecology and the Environment 9: 374-375.

13. Silvano RAM, Begossi A (2012) Fishermen's local ecological knowledge on Southeastern Brazilian coastal fishes: contributions to research, conservation, and management. Neotropical Ichthyology 10: 133-147.

14. Bender MG, Floeter SR, Hanazaki N (2013) Do traditional fishers recognise reef fish species declines? Shifting environmental baselines in Eastern Brazil. Fisheries Management and Ecology 20: 58-67.

15. Begossi A, Lopes PF, Silvano RAM (2012) Co-management of reef fisheries of the snapper-grouper complex in a human ecological context in Brazil. In: Kruse $\mathrm{GH}$, Browman HI, Cochrane KL, Evans D, Jamieson GS, et al. (eds) Global progress in ecosystem-based fisheries management: 353-373.

16. Begossi A, Hanazaki N, Ramos RM (2004) Food chain and the reasons for fish food taboos among Amazonian and Atlantic Forest fishers (Brazil). Ecological Applications 14: 1334-1343.

17. Begossi A, Salivonchyk SV, Barreto T, Nora V, Silvano RAM (2012) Smallscale fisheries and conservation of dusky grouper (garoupa), Epinephelus marginatus (Lowe, 1834) in the Southeastern Brazilian coast. Science Journal of Agricultural Research and Management. Article ID sjarm-174.

18. Begossi A, Silvano RAM (2008) Ecology and Ethnoecology of dusky grouper, 
Citation: Begossi A, Salivonchyk S, Renato Silvano AM (2016) Collaborative Research on Dusky Grouper (Epinephelus Marginatus): Catches from the Small-Scale Fishery of Copacabana Beach, Rio De Janeiro, Brazil. J Coast Zone Manag 19: 428. doi:10.4172/2473-3350.1000428

Page 6 of 6

garoupa, [Epinephelus marginatus (Lowe, 1834)] along the coast of Brazil. Journal of Ethnobiology and Ethnomedicine 4: 1-20.

19. Andrade ÁB, Machado LF, Hostim-Silva M, Barreiros JP (2003) Reproductive biology of the dusky grouper Epinephelus marginatus (Lowe, 1834). Brazilian Archives of Biology and Technology 46: 373-382.

20. Condini MV, Fávaro LF, Varela AS, Garcia AM (2014) Reproductive biology of the dusky grouper (Epinephelus marginatus) at the southern limit of its distribution in the south-western Atlantic. Marine and Freshwater Research 65: $142-152$

21. Silvano RAM, MacCord PF, Lima RV, Begossi A (2006) When does this fish spawn? Fishermen's local knowledge of migration and reproduction of Brazilian coastal fishes. Environmental Biology of Fishes 76: 371-386.

22. Begossi A (2008) Local knowledge and training towards management Environment Development and Sustainability 10: 591-603.

23. Silvano RAM, Begossi A (2010) What can be learned from fishers? An integrated survey of fishers' local ecological knowledge and bluefish (Pomatomus saltatrix) biology on the Brazilian coast. Hydrobiologia 637: 3-18

24. Nehrer R, Begossi A (2000) Fishing at Copacabana (Rio de Janeiro): local strategies in a global city. Ciência e Cultura 52: 26-30.

25. Begossi A, Camargo E, Carpi J (2013) Os Mapas da Pesca Artesanal Pesqueiros e Pescadores na Costa do Brasil. RiMa, Sao Carlos, Brazil.

26. Begossi A, Clauzet M, Dyball R (2015) Fisheries, Ethnoecology, Human Ecology and Food security: a review of concepts, collaboration and teaching. Seguranca Alimentar e Nutricional. Campinas 22: 574-590.

27. Johannes RE (1981) Words of the lagoon: fishing and marine lore in the Palau district of Micronesia. University of California Press, Berkeley: 245.

28. Ruddle K (2000) Systems of knowledge: dialogue, relationships and process. Environment, Development and Sustainability 2: 277-304.

29. Berkes F (2008) Small-scale fisheries: alternatives to conventional management. In: Pinedo D, Soria C (edts) El Manejo de las Pesquerias en la Amazonia. IDRC and Instituto del Bien Comun, Ottawa: 447-463.

30. Gerhardinger LC, Freitas MO, Bertoncini AA, Hostim-Silva M (2006) Collaborative approach in the study of the reproductive biology of the dusky grouper Epinephelus marginatus (Lowe, 1834) (Perciformes: Serranidae). Acta Scientiarum-Biological Sciences 28: 219-226.

31. Petrere JM (1978) Pesca e esforço de pesca no Estado do Amazonas. I. Esforço e captura por unidade de esforço. Acta Amazonica 8: 439-454.

32. Zukowski S, Curtis A, Watts RJ (2011) Using fisher local ecological knowledge to improve management: the Murray crayfish in Australia. Fisheries Research 110:120-127.
33. Lópes-Gómez MJ, Aguilar-Perera A, Perera-Chan L (2014) Mayan diver-fishers as citizen scientists: detection and monitoring of the invasive red lionfish in the Parque Nacional Arrecife Alacranes, Southern Gulf of Mexico. Biological Invasions 16: 1351-1357.

34. Fischer J, Jorgensen J, Josupeit H, Kalikoski D, Lucas CM (2015) Fishers' knowledge and the ecosystem approach to fisheries: applications, experiences and lessons in Latin America. FAO Fisheries and Aquaculture: 278.

35. Condini MV, Garcia AM, Vieira JP (2007) Descrição da pesca e perfil socioeconômico do pescador da garoupa-verdadeira Epinephelus marginatus (Lowe)(Serranidae: Epinephelinae) no Molhe Oeste da Barra de Rio Grande, Rio Grande do Sul, Brasil. Pan-American Journal of Aquatic Sciences 2: 279-287.

36. Begossi A, Lopes PF, Oliveira LEC, Nakano H (2010) Ecologia de Pescadores Artesanais da Baía da Ilha Grande. RiMa, Sao Carlos, Brazil.

37. Begossi A, Lopes PF (edts) (2014) Comunidades pesqueiras de Paraty (Paraty small-scale fisheries, suggestions for management - sugestões para manejo). RiMa, Sao Carlos, Brazil.

38. Birkeland C, Dayton PK (2005) The importance in fishery management of leaving the big ones. Trends in Ecology \& Evolution 20: 356-358.

39. Garcia SM, Kolding J, Rice J, Rochet MJ, Zhou S, et al. (2012) Reconsidering the consequences of selective fisheries. Science 335: 1045-1047.

40. Feary DA, Cinner JE, Graham NAJ, Januchowski-Hartley FA (2011) Effects of customary marine closures on fish behavior, spear-fishing success, and underwater visual surveys. Conservation Biology 25: 341-349.

41. Hamilton RJ, Potuku T, Montambault JR (2011) Community-based conservation results in the recovery of reef fish spawning aggregations in the Coral Triangle. Biological Conservation 144: 1850-1858.

42. IBAMA. Portaria No 73/03-N, de 24 de novembro de 2003. Diário Oficial da União de 4 de dezembro de 2003, Seção 1. Estabelece o tamanho mínimo de captura de espécies marinhas e estuarinas do litoral sudeste/sul do Brasil. 2003: 109

43. Seyboth E, Condini MV, Albuquerque CQ, Varela JAS, Velasco G, et al. (2011) Age, growth, and reproductive aspects of the dusky groupe Mycteroperca marginata (Actinopterygii: Epinephelidae) in a man-made rocky habitat in southern Brazil. Neotropical Ichthyology 9: 849-856.

44. Bodilis P, Ganteaume A, Francour P (2003) Presence of 1 year-old dusky groupers along the French Mediterranean coast. Journal of Fish Biology 62: $242-246$.

45. Begossi A (2006) Temporal stability in fishing spots: conservation and comanagement in Brazilian artisanal coastal fisheries. Ecology and Society 11: 5.

46. Froese $\mathrm{R}$ (2004) Keep it simple: three indicators to deal with overfishing Fish and fisheries 5: 86-91.

47. Priolli RHG, Stabellini NNS, Bajay MM (2014) Diversidade genética de uma espécie em perigo de extinção: a garoupa Epinephelus marginatus. In: Begossi A, Lopes PF (edts) Comunidades pesqueiras de Paraty-sugestões para manejo. RiMa, Sao Carlos, Brazil: 27-39. 